\title{
GLOSA DO WYROKU SĄDU NAJWYŻSZEGO Z DNIA 24 CZERWCA 2014 R., SYGN. I CSK 477/13**
}

\section{COMMENT ON THE JUDGEMENT OF THE SUPREME COURT OF 24 JUNE 2014, I CSK 477/13}

\section{STRESZCZENIE}

Przedmiotem glosy jest analiza art. 126 ustawy z dnia 16 kwietnia 2004 r. o ochronie przyrody w kontekście możliwości dochodzenia roszczeń odszkodowawczych od Skarbu Państwa z tytułu szkody wyrządzonej nieruchomości przez zwierzęta podlegające ochronie. W analizowanym wyroku Sąd Najwyższy podzielił stanowisko, w myśl którego z roszczeniem z art. 126 ust. 4 u.o.p. może wystąpić nie tylko

* Magister prawa, asystent w Katedrze Prawa Cywilnego i Bankowego Wydziału Prawa i Administracji Uniwersytetu Mikołaja Kopernika.

** Legalis nr 1079890. 
właściciel, lecz również dzierżawca takiej nieruchomości. Pogląd ten należy podzielić.

\section{Słowa kluczowe}

Szkoda wyrządzona przez zwierzęta pod ochroną; odpowiedzialność odszkodowawcza; roszczenia dzierżawcy nieruchomości należącej do Skarbu Państwa.

\section{ABSTRACT}

The aim of the comment is to analyse article 126 of the Nature Conservation Act of 2004 concerning the possibility of suing the State Treasury for a damage caused by protected animals to a real property. In its judgement the Supreme Court confirmed that not only the owner but also the tenant of a real property has legal standing in case of such a damage. The Supreme Court's opinion merits an approval.

\section{Keywords}

Damage caused by protected animals; liability; tenant's claim against the State Treasury.

\section{GLOSA}

I.

W obecnym obrocie prawnym dostrzegalne są potrzeby ochrony przyrody przy jednoczesnej ochronie przysługujących jednostce praw podmiotowych. Urzeczywistnienie tych postulatów może napotykać na trudności. W praktyce jest to szczególnie widoczne na tle odpowiedzialność Skarbu Państwa za wyrządzone przez zwierzęta (podlegające ochronie gatunkowej) szkody (w tym na nieruchomościach stanowiących przedmiot umowy dzierżawy). Kwestia ta nabiera coraz większego znaczenia, przybierając stopniowo wymiar ogólnonarodowy. Dotyczy już nie tylko podmiotów profesjonalnych prowadzących działal- 
ność gospodarczą, ale także osób fizycznych będących właścicielami działek rekreacyjnych ${ }^{1}$. Na tle glosowanego wyroku powstało ważkie zagadnienie: w jakich sytuacjach istnieje prawna możliwość dochodzenia przez dzierżawcę roszczeń odszkodowawczych od Skarbu Państwa z tytułu szkody wyrządzonej na przedmiocie dzierżawy przez zwierzęta podlegające ochronie.

II.

Stan faktyczny przedstawiał się następująco. W $2001 \mathrm{r}$. dzierżawca (powód) zawarł $\mathrm{z}$ wydzierżawiającym (Agencją Nieruchomości Rolnych w R.) umowę dzierżawy gospodarstwa rybackiego na piętnaście lat. Dzierżawca zobowiązał się do utrzymania przedmiotu dzierżawy w stanie niepogorszonym (na własny koszt), z wyjątkiem pogorszenia wynikającego z normalnego zużycia rzeczy. Na terenie dzierżawionego przez powoda gospodarstwa stwierdzono szkody wyrządzone przez bobry (gatunek zwierząt podlegający całkowitej ochronie). Uszkodzone zostały groble. Państwowa Straż Leśna potwierdziła zaistnienie szkody i oszacowała jej wysokość. Szkody zostały naprawione na koszt powoda w latach 2007-2009. Następnie powód wystąpił przeciwko Skarbowi Państwa o odszkodowanie, a jako jego wysokość podał koszty napraw uszkodzonych przez bobry grobli.

III.

W celu odpowiedzi na wskazane we wstępie pytanie warto zaznaczyć, że odpowiedzialność Skarbu Państwa za szkody wyrządzone przez zwierzęta może wynikać z różnych podstaw prawnych. Zależy m.in. od klasyfikacji zwierząt. W przypadku zwierząt będących pod ochroną: gatunek żubr, wilk, ryś, niedźwiedź czy bóbr, podstawę odpowiedzialności stanowi art. 126

1 Por. zwłaszcza ostatnie wyroki Trybunały Konstytucyjnego: wyrok z dnia 3 lipca 2013 r., P 49/11, OTK-A 2013/6/73, Dz.U.2013/842 oraz wyrok z dnia 21 lipca 2014 r., K 36/13, OTK-A 2014/7/75, Dz.U.2014/1002 
ustawy z dnia 16 kwietnia 2004 r. o ochronie przyrody ${ }^{2}$. Odpowiedzialność za niektóre inne gatunki chronione jest uregulowana art. 50 ust. 1 w zw. z art. 46-49 ustawy z dnia 13 października 1995 r. Prawo łowieckie ${ }^{3}$. Skarb Państwa może także ponosić odpowiedzialność jako podmiot zobowiązany w oparciu o treść przepisu art. 431 Kodeksu cywilnego (dalej: k.c.). Wreszcie nie jest wykluczone wyjątkowe przypisanie odpowiedzialności Skarbowi Państwa za szkodę na przedmiocie dzierżawy (wyrządzoną przez inne niż wskazane uprzednio zwierzęta) na podstawie art. $417^{2}$ k.c. ${ }^{4}$ lub innych przepisów ogólnych (pod warunkiem wykazania odpowiednich przesłanek) ${ }^{5}$.

W praktyce obrotu szczególnego znaczenia w rozważanym zakresie nabierają szkody wyrządzone na przedmiocie dzierżawy (jego uszkodzenie lub zniszczenie) przez bobry. Sytuacja ta występuje najczęściej w różnego typu gospodarstwach rybackich ${ }^{6}$. Szkody ulegają systematycznemu wzrostowi, przybierając coraz większe rozmiary w skali kraju ${ }^{7}$ Stąd szczególne znaczenie dla analizowanego zagadnienia dopuszczalności dochodzenia roszczeń odszkodowawczych od Skarbu Państwa przez dzierżawcę ma art. 126 u.o.p.

Odpowiedzialność Skarbu Państwa ujęta w treści przepisu art. 126 u.o.p. ma charakter odpowiedzialności cywilnej za czy-

2 T. j. Dz.U.2015 r., poz. 1651, ze zm. (dalej: u.o.p.).

3 T.j. Dz.U. z 2015 r., poz. 2168 ze zm.; por. wyrok SN z dnia 22 sierpnia 2001 r., V CKN 431/00, OSNIC 2002, nr 4, poz. 53 wraz z aprobującą glosą B. Rakoczego.

4 Zob. wyrok SN z dnia 7 grudnia 2012 r., II CSK 239/12, LEX.

5 Por. uchwała SN z dnia 7 grudnia 2007 r., III CZP 120/07, LEX z glosami aprobującymi M. Goettel i B. Rakoczego; szerzej na temat analizowanych podstaw odpowiedzialności zob. np. K. Gruszecki, Ustawa o ochronie przyrody, komentarz, Warszawa 2010, s. 533-537; W. Radecki, Ustawa o ochronie przyrody, komentarz, Warszawa 2012, s. 514-524 wraz ze wskazaną w tych publikacjach dalszą literaturą i orzecznictwem.

6 Oprócz glosowanego wyroku zob. np. wyrok SN z dnia 17 października 2008r., I CSK 136/08, LEX nr 548797.

7 W samym tylko 2013 r. kwoty wypłacone tytułem zgłoszonych roszczeń odszkodowawczych za szkody wyrządzone przez bobry oszacowano na ponad 15 mln złotych - por. druk sejmowy nr 2355, Sejmu Rzeczypospolitej Polskiej VII kadencji, z dnia 11 kwietnia 2015 r., s. 5-6. 
ny niedozwolone ${ }^{8}$, przy czym posiada wiele cech swoistych (np. Skarb Państwa odpowiada jedynie do wysokości rzeczywiście poniesionych strat - damnum emergens). Jest odpowiedzialnością obiektywną ${ }^{9}$. Sąd Najwyższy wskazał, że jej cywilnoprawny charakter sprawia, że do kwestii nieuregulowanych w treści wskazanego przepisu zastosowanie znajdują reguły ogólne kodeksu cywilnego. W celu uzyskania odszkodowania od Skarbu Państwa za szkodę wyrządzoną przez zwierzęta na przedmiocie dzierżawy konieczne jest wykazanie przez dzierżawcę rzeczywistej szkody, jaka została przez niego poniesiona ${ }^{10}$. Nasuwa się pytanie, w jakich sytuacjach dzierżawca ponosiłby rzeczywistą szkodę w związku z uszkodzeniem (zniszczeniem) przedmiotu dzierżawy.

IV.

Zasadniczo dzierżawca korzysta z cudzych praw na rzeczy. W związku z tym uszkodzenia lub zniszczenie przedmiotu dzierżawy będzie stanowiło najczęściej szkodę dla wydzierżawiającego (zwykle właściciela). W pewnych sytuacjach jednak obowiązek dokonania stosowanych nakładów (napraw) na przedmiot dzierżawy obciąża dzierżawcę ${ }^{11}$. Jak się wydaje, w takiej sytuacji szkoda wyrządzona na przedmiocie dzierżawy przez zwierzęta chronione będzie musiała zostać usunięta przez dzierżawcę, co spowoduje powstanie po jego stronie rzeczywistych kosztów, a w konsekwencji spowoduje możliwość domagania się odszkodowania od Skarbu Państwa na podstawie

8 Zob. np. wyrok SA w Katowicach z dnia 5 marca 2010 r., I ACa 6/10, LEX nr 1120382; W. Radecki, op. cit., s. 513-514.

9 Por. np. B. Rakoczy, Ciężar dowodu $w$ polskim prawie ochrony środowiska, Warszawa 2010, s. 172; W. Radecki, op. cit., s. 528.

10 Zob. wyrok SN z dnia 17 października 2008 r., I CSK 136/08, LEX nr 548797, który został wydany w stanie faktycznym podobnym do zaistniałego w glosowanym wyroku (szkoda wyrządzona przez bobry na przedmiocie umowy dzierżawy).

11 Por. por. wyrok SN z dnia 19 listopada 2004 r., II CK 158/04, LEX nr 277867 - dotyczący umowy najmu, jednak mogący mieć tu odpowiednie zastosowanie (art. 694 k.c.). 
przepisu art. 126 u.o.p. ${ }^{12}$ Konstrukcja taka została zaakceptowana przez Sąd Najwyższy w glosowanym orzeczeniu, do czego należy odnieść się z aprobatą. Powstaje jednak kwestia, jakie konkretne sytuacje uzasadniałyby dochodzenie przez dzierżawcę wskazanych roszczeń.

Można wskazać kilka podstaw umożliwiających dzierżawcy dochodzenie odszkodowania w oparciu o treść przepisu art. art. 126 u.o.p. Najczęściej będą to przepisy normujące umowę dzierżawy ${ }^{13}$. Jak się wydaje, nie jest wykluczone zastosowanie innych przepisów, przy czym roszczenia musiałyby wynikać z odrębnego od umowy dzierżawy stosunku prawnego (np. prowadzenia cudzych praw bez zlecenia) ${ }^{14}$.

Przede wszystkim podstawę dochodzenia odszkodowania mogłaby stanowić odpowiednia umowa stron stosunku dzierżawy (np. nakładająca na dzierżawce obowiązek dokonywania napraw przedmiotu dzierżawy w przypadku uszkodzenia lub zniszczenia). Przepisy dotyczące nakładów mają charakter dyspozytywny, strony mogą swobodnie (w zakresie dopuszczalności wskazanej w art. $353^{1}$ k.c.) ustalić kogo i w jakim zakresie będą one obciążały ${ }^{15}$. Ustalenia te mogą być dokonane zasadniczo w dowolnej formie, w tym konkludentnej ${ }^{16}$.

Powstaje pytanie, czy strony mogą dokonać takiej zmiany nawet po wystąpieniu szkody oraz czy miałoby to negatywny

12 Por. wyrok SN z dnia 17 października 2008r., I CSK 136/08, op. cit.

13 Por. np. wyrok SN z dnia 16 stycznia 1991r., I CR 776/90, OSP 1992/5/108; podobnie Z. Radwański w glosie krytycznej do tego wyroku; wyrok SA w Warszawie z dnia 16 marca 2011r., VI ACa 852/10, „Gazeta Prawna -Tygodnik Prawo w Firmie" 2011/128/7.

14 Por. np. wyrok SA w Szczecinie z dnia 6 lutego 2014r., I ACa 616/13, LEX nr 1454620; por. także H. Ciepła, w: Komentarz do kodeksu cywilnego, t. II, Księga trzecia: zobowiązania, red. G. Bieniek, Warszawa 2005, s. 244.

15 Zob. np. wyrok SN: wyrok z dnia 26 czerwca 2008 r., II CSK 69/08, LEX nr 548800; wyrok SA w Poznaniu z dnia 14 maja 2014 r., I ACa 76/14, LEX nr 1489135.

16 Przy czym przy ewentualnej ocenie, czy do takiej zmiany umownej doszło, należałoby zbadać wszelkie okoliczności konkretnej sprawy; nie byłoby wystarczające samo tolerowanie dokonywania napraw przez wydzierżawiającego - por. wyrok SA w Poznaniu z dnia 12 lutego 2014 r., I ACa 1254/13, LEX nr 1439255. 
wpływ na dochodzenie przez dzierżawcę odszkodowania od Skarbu Państwa. Jak się wydaje, zmiana taka może być zasadniczo dokonana w wybranym przez strony czasie i nie miałaby negatywnego wpływu na dochodzenie zwrotu kosztów w oparciu o art. 126 u.o.p. Podstawowym elementem odszkodowania jest prawidłowe ustalenie szkody ${ }^{17}$, zaś sama zmiana podmiotów uprawnionych do żądania zapłaty nie ma na to wpływu. Ponadto wydzierżawiający na zasadzie swobody umów może przenieść w dowolnym momencie na dzierżawce przysługujące mu roszczenia ${ }^{18}$.

Drugą z podstaw umożliwiających dochodzenie przez dzierżawcę odszkodowania w oparciu o treść przepisu art. 126 u.o.p. mogłoby być właśnie wskazane przeniesienie przysługujących wydzierżawiającemu roszczeń na dzierżawcę (jako praw podmiotowych: wierzytelność $)^{19}$.

Po trzecie można nadmienić, że dzierżawca mógłby dochodzić od Skarbu Państwa odszkodowania (w zakresie ujętym w art. 126 u.o.p.), jeśli dokonał napraw (obciążających wydzierżawiającego ${ }^{20}$ ) zgodnie $\mathrm{z}$ treścią przepisu art. 663 k.c. W zW. z art. 694 k.c. W braku odmiennej woli stron naprawy w celu utrzymywania przedmiotu dzierżawy w stanie przydatnym do umówionego użytku zasadniczo obciążają wydzierżawiającego. Jeśli więc zwierzęta (wskazane w art. 126 u.o.p.) uszkodzą przedmiot dzierżawy, zaś wydzierżawiający nie dokona napraw, to dzierżawca (po spełnieniu przesłanek z art. 663 k.c.) może ich dokonać na jego koszt ${ }^{21}$.

17 K. Gruszecki, op. cit., s. 538.

18 Zob. wyrok SN z dnia 17 października 2008 r., I CSK 136/08, op. cit.

19 Por. ibidem.

20 Szerzej na temat które naprawy obciążają wydzierżawiającego zob. np. A. Lichorowicz, w: System Prawa Prywatnego, t. 8, Prawo zobowiąań część szczegótowa, red. J. Panowicz-Lipska, Warszawa 2011, s. 207 i 208.

21 Por. np. uchwałą SN z dnia 19 marca 1975 r., III CZP 13/75, OSNC 1976/2/25, z glosą Z. Radwańskiego; wyrok SN z dnia 14 grudnia 2011r., I CSK 122/11, LEX nr 1147726; zob. też G. Kozieł, w: Kodeks cywilny, komentarz, t. III, Zobowiązania - część szczególna, red. A. Kidyba, Warszawa 2010, s. 365 . 
Nasuwa się kwestia, czy skoro przepis art. 663 k.c. umożliwia dochodzenie zwrotu nakładów (napraw) od wydzierżawiającego, to możliwe byłoby na jego podstawie dochodzenie roszczeń także od Skarbu Państwa (art. 126 u.o.p.). Jak się wydaje, odpowiedź powinna być pozytywna ${ }^{22}$. Jak zostało wskazane, regulacja art. 126 u.o.p. kładzie nacisk głównie na fakt wystąpienia szkody ${ }^{23}$, wskazując jednocześnie pośrednio, że nie tylko właściciel może wystąpić z roszczeniem (art. 126 ust. 4 u.o.p.). W sytuacji uszkodzenia przez zwierzęta przedmiotu dzierżawy i naprawienia go przez dzierżawcę (zgodnie z przesłankami wskazanymi w art. 663 k.c. w zw. z art. 694 k.c.) powstaje po jego stronie rzeczywista szkoda (uszczerbek majątkowy), co uzasadniałoby żądanie odpowiedniego odszkodowania od Skarbu Państwa ${ }^{24}$. Przyjęcie odmiennego zapatrywania ${ }^{25}$ nie znajduje chyba aksjologicznego uzasadnienia, skutkowałoby niepotrzebnym opóźnieniem w wypłacie środków pieniężnych, a w konsekwencji mogłoby mieć negatywny wpływ na obrót gospodarczy, stwarzając niecelowe utrudnienia.

Dokonanie zapłaty przez Skarb Państwa dzierżawcy powodowałaby, jak się wydaje, skutek w postaci braku możliwości żądania przez dzierżawcę zapłaty od wydzierżawiającego na podstawie art. 663 k.c. w zw. z art. 694 k.c. (przestaje istnieć szkoda w majątku dzierżawcy). Nie powstawałby także problem podwójnej zapłaty przez Skarb Państwa odszkodowania za to samo zdarzenie (jednocześnie dzierżawcy i wydzierżawiające$\mathrm{mu}$ ). Jeżeli bowiem przedmiot dzierżawy zostanie naprawiony przez którąkolwiek ze stron umowy dzierżawy, druga strona nie będzie już mogła skutecznie wystąpić o zapłatę odszkodowania, gdyż szkoda przestanie istnieć (przedmiot został naprawiony).

22 Por. H. Ciepła, op. cit., s. 244.

23 K. Gruszecki, op. cit., s. 538.

24 Por. wyrok SA w Krakowie z dnia 23 maja 2014 r., I ACa 390/14, LEX nr 1621129 - wskazujący, że szkody niezależne od wynajmującego (wydzierżawiającego) powinno się raczej dochodzić od podmiotów, które ponoszą za nie odpowiedzialność.

25 Tzn. dzierżawca miałby wezwać do zapłaty wydzierżawiającego, ten z kolei zgłosiłby roszczenie do Skarbu Państwa, po czym Skarb Państwa wypłaciłby odszkodowanie wydzierżawiającemu, a on z kolei przekazał je dzierżawcy. 
Wskazane sytuacje należą do najczęstszych, które mogą powodować powstawanie roszczeń odszkodowawczych dzierżawcy do Skarbu Państwa w oparciu o treść przepisu art. 126 u.o.p. Jak się wydaje, niewykluczone są także inne sytuacje. W szczególności mogłyby one wynikać z zawartej na podstawie art. 126 ust. 4 u.o.p. umowy pomiędzy dzierżawcą a Skarbem Państwa (odpowiednią jego jednostką), mającej na celu zabezpieczenie przedmiotu dzierżawy przed szkodami spowodowanymi przez zwierzęta podlegające ochronie ${ }^{26}$.

W doktrynie i orzecznictwie trafnie wskazuje się, że celowe jest objęcie szeroką ochroną podmiotów, które doznały szkody w wyniku działalności zwierząt będących pod ochronąą Sprzyja to z jednej strony lepszej ochronie ich praw podmiotowych, a z drugiej strony służy pełniejszemu urzeczywistnieniu postulatu ochrony przyrody (zwłaszcza gatunków zagrożonych wyginięciem $)^{28}$. Należy więc poprzeć postulat szerokiego współdziałania podmiotów prywatnych z odpowiednimi jednostkami Skarbu Państwa w celu ochrony przyrody, realizowany między innymi także przez wypłatę odszkodowań za szkody powstałe na przedmiocie dzierżawy. Glosowany wyrok Sądu Najwyższego, wpisujący się w te tendencje, zasługuje na aprobatę.

\section{Kontakt e-mail:}

drewek@umk.pl

26 Wyłącznie tytułem przykładu: umowa, w której strony mogłyby zawrzeć postanowienia, że dzierżawca dokona na własny koszt określonych nakładów (np. zamontowanie określonych urządzeń), które miałyby zapobiegać szkodom w przyszłości, zaś Skarb Państwa zobowiązałby się do zapłaty dzierżawcy szkód (nie tylko związanych z przedmiotem dzierżawy), jakie poniósłby, gdyby zabezpieczenia okazały się nieskuteczne

27 Por. np. wyrok TK z dnia 3 lipca 2013 r., P 49/11, op. cit.; wyrok TK z dnia 21 lipca 2014 r., K 36/13, op. cit.

28 Por. np. B. Rakoczy, op. cit., s. 163; idem, glosa do wyroku SN z dnia 22 sierpnia 2001 r., V CKN 431/00, OSP 2002/12/159; K. Gruszecki, op. cit., s. $542-543$. 